\title{
Surveying the Degree of Domestic Violence against Women and Its Effective Factors in Married Women in Sabzevar
}

\author{
Ahmadi $Z^{1}$, Mehri $A^{2}$, Nadrian $\mathbf{H}^{3}$, Hashemian $\mathbf{M}^{4}$, Rahayy $Z^{5}$, Mehri $A^{6}$ \\ ${ }^{1}$ MSc Student of Health Education and Health Promotion, School of Public Health, Qom University of Medical Sciences, Qom, Iran. \\ ${ }^{2} \mathrm{MSc}$ Student of Epidemiology, School of Public Health, Tehran University of Medical Sciences, Tehran, Iran. ${ }^{3}$ Assistant Professor \\ in Health Education and promotion, School of Health, Tabriz University of Medical Sciences, Tabriz, Iran. ${ }^{4}$ Assistant Professor in \\ Health Education and Promotion, School of Health, Sabzevar University of Medical Sciences, Sabzevar, Iran. ${ }^{5}$ Assistant Professor, \\ Health Education Department, School of Public Health, Yazd Shahid Sadoughi University of Medical Sciences, Yazd, Iran. \\ ${ }^{6}$ Assistant Professor in Health Education and Promotion, School of Health, Sabzevar University of Medical Sciences, Sabzevar, \\ Iran.
}

\begin{abstract}
Background: Violence against women is a global phenomenon experienced in the private and public areas of life. The aim of this study was to investigating the degree of violence and identifying the relevant factors for recognition, prevention and control of this phenomenon is essential. This study was conducted to determine the degree of domestic violence and its related factors in married women in Sabzevar in 2018. Methods: In this descriptive-analytical study; 360 married women in Sabzevar were selected by cluster sampling method $(10 \times 40)$ and examined. A questionnaire was used to collect data, Its validity was determined by the panel of experts and its reliability was determined by Cronbach's alpha(0.65-0.83)and self-report completed for data analysis, descriptive tests and regression-based path analysis were used. Results: According to the results, the average rate of violence against women was reported by $85.40 \pm 39.55$ out of a total of 290 grades. Social factors $(\beta=0.072)$, family factors $(\beta=0.075)$, and related factors of couples $(\beta=0.640)$ which explained $39 \%$ of total variance of violence. Among these factors, the effect of factors related to couples was more than other factors. Violence rate against women includes legal violence $(19 \%)$, verbal violence $(18 \%)$ and emotional violence $(15 \%)$ were the most significant type of violence in the community. Conclusion: The degree of violence in the investigated society was significant. Due to its consequences, the degree of violence in the population should be reduced. Considering the most important factors affecting the occurrence of violence related to couples, such as the lack of training of couples and the lack of ability of couples to control anger and some of the strategies of women to deal with violence. Therefore, it is necessary for the relevant authorities to intervene in empowering couples to deal with this problems. The amount of referral to the counselor for solving very few issues should be increased by taking appropriate measures from the relevant authorities. Considering couples' suggestions such as reducing unemployment and economic problems, and also the government can help reduce the risk of violence between couples.
\end{abstract}

Keywords: Domestic Violence- married women- Sabzevar

Asian Pac J Environment and Cancer, 1 (2), 49-53

Submission Date: 08/11/2018 Acceptance Date: 10/10/2018

\section{Introduction}

Violence against women is a form of gender-based violent behavior that causes physical, sexual or psychological harm or suffering of women. Such behaviors can be accompanied by threats, coercion or deprivation of freedom and liberty. Violence against women as a global phenomenon experienced in the private and public areas of life is a serious threat to health and human rights. This annoying behavior by a husband against a woman occurs in the privacy of the family and away from the eyes of the people of the community and often occurs secretly, which can be lead to physical and psychological harm to an individual, and also causes

Corresponding Author:

Dr. Mehri A

Assistant Professor in Health Education and promotion, School of Health, Sabzevar University of Medical Sciences, Sabzevar, Iran.

Email: hadimehri1386@gmail.com 
irreparable social consequences [1-2]. According to the World Bank, domestic violence is more likely to endanger the health of women aged 15-44 than diseases such as breast cancer, uterine cancer and accidents [3]. Cancer has always been the most important of all diseases. The kinds of cancers, for instance, breast cancer, ovarian cancer, lung cancer, gastric cancer and brain cancer [10-4]. Considering the types of violence against women is the most common type of domestic violence, with $90 \%$ of the victims of domestic violence being women [11]. According to the World Health Organization (WHO), in 2016, one- third women aged 15-49 were at risk of physical and sexual violence [13], which is in different regions, the WHO estimates the rate of violence in the Southeast Asian region was 38\% [12]. In several studies in Iran that reported violence rates between $6 \%$ and $95 \%$ [13-16]. For example of this study, Hajnasiri et al. (2016), the rate of violence in the whole country was reported by $66 \%$. Geographically, the rate of violence in the east and south of the country was $70 \%, 59 \%$ in the center of the country, and in the west and north of the country were $75 \%$ and $62 \%$ respectively [16]. In another study, Hosseini et al. (2013), a total of violence rates in Sabzevar was reported at $78 \%$. Considering the types of violence, psychological violence $(66.5 \%)$, Sexual violence $(57 \%)$ and physical violence $(35 \%)$ were the most common forms of violence [17]. In another study of Asadi et al. (2013) in Sabzevar, the total of violence was reported at $76.7 \%$, and the verbal violence $(97 \%)$, sexual violence $(64 \%)$ and physical violence $(54 \%)$ were the most common forms of violence [18]. Domestic violence against women imposes many negative consequences on the family and even the men themselves; include genital tract bleeding during pregnancy, low birth weight, wound, cuts, bruises, internal injuries, brain damage, genital damage, abortion and sexual diseases, depression, perceptual disability, weakening of self confidence, inadequate family management, avoidance of social participation, weakening of the motivation for progress and efficiency in the workplace, occurrence of physical and psychological pains (headache, back pain, inaccurate pain and chronic and psychological fatigue) and finally, the increasing collapse of families and divorces. Death is the worst harm caused by domestic violence against women [19-21].

Domestic violence has a huge impact on the quality of life of women and the health of the family and has been neglected as one of the social issues. Planning for controlling violence require an accurate understanding and the study of the causes related with it. Since there are few studies in the country and especially in Sabzevar city. Therefore, this study was conducted to determine the degree of domestic violence against women and its effective factors in married women in Sabzevar.

\section{Materials and Methods}

This survey is across-sectionaland descriptive-analytical study. The population of this study was all married women in Sabzevar who had at least one year of their marriage history, had experienced domestic violence and were randomly selected to participate in the study. The case study was conducted with a confidence level of $95 \%(\alpha=0.05)$ and the sample size was 384 , which were selected by multi-stage cluster sampling. For this purpose, the city of Sabzevar divided into five areas according to the city square and from each area four streets were randomly selected and also from each street, two alleys were randomly selected. To complete the questionnaire after obtaining a certificate from the Sabzevar university of medical sciences in order to run the project, the target group was provided with a description of the aims of the study and how to complete the questionnaire, and the questionnaire was completed by the women himself. To collect data, a questionnaire adapted to the culture of the country was designed. Its validity was confirmed by the panel of experts and its reliability was confirmed by internal consistency $(\alpha=0.69-0.87, N=30)$. The questionnaire consisted of two parts: the first part includes questions about demographic characteristics (age, duration of marriage, number of children, wife and spouse's educational background, type of marital and non-familial marriage, occupation of men and women). The second part includes questions about types of violence, factors affecting violence, the strategy of women in the event of domestic violence and the suggestion of factors to reduce violence by the government. To answer each of these questions, the Likert scale was used, which was scored as 1-5. Data were analyzed by descriptive and analytical tests using SPSS20 software $(\mathrm{P}<0.05$ was considered statistically significant $)$.

\section{Results}

The average age of the women was $39.50 \pm 10.93$ years $(\mathrm{R}=16-76)$ and the age of their husbands was $34.48 \pm 10.27$ years $(\mathrm{R}=21-80)$. The mean duration of marriage was $13.91 \pm 10.54$ years $(\mathrm{R}=1-57)$. They had an average of 1.65 children $(\mathrm{R}=0-8) .67 .3 \%$ of them had familial marriages. Most of them were educated $(76 \%)$ and most of their husbands $(69 \%)$ had diplomas and higher than diplomas. The job of most of them (70\%) were housewives and most of their husbands (62\%) were freelancer. According to the average results of violence against women was reported by $85.40 \pm 39.55$ out of a total of 290 grades. Social factors $(\beta=0.072)$, family factors $(\beta=0.075)$, and related factors of couples ( $\beta=0.640)$, which explained $39 \%$ of total variance of violence. Considering these factors, the effect of factors related to couples was higher than other factors (Table 1). The types of violence, legal violence (19\%), verbal violence (18\%) and emotional violence $(15 \%)$ were

Table 1. Assessing the Predictor the Rate of Violence against Women in the Community Surveyed

\begin{tabular}{lccc}
\hline Factors & Beta & Significant Level & $\mathrm{R}^{2}$ \\
\hline Social factors & 0.072 & 0.352 & 0.392 \\
Family factors & 0.075 & 0.227 & \\
Factors related to couples & 0.640 & 0.000 & \\
\hline
\end{tabular}


Table 2. The Most Important Causes of Violence, the Strategy of Women in the Event of Violence, and the Suggested Solutions to the Government to Reduce Violence

\begin{tabular}{|c|c|c|c|c|c|}
\hline The most important causes of violence & Percentage & $\begin{array}{l}\text { women's strategy in the event of } \\
\text { violence }\end{array}$ & Percentage & $\begin{array}{l}\text { proposed strategies to reduce } \\
\text { violence }\end{array}$ & Percentage \\
\hline Working and financial problems & 34.4 & $\begin{array}{l}\text { talking and trying to solve their } \\
\text { problem with the husband at the } \\
\text { right time }\end{array}$ & 48.7 & $\begin{array}{l}\text { decrease in unemployment rate } \\
\text { in the community }\end{array}$ & 91.9 \\
\hline $\begin{array}{l}\text { Lacking proper education and training your } \\
\text { husband at his father's home }\end{array}$ & 29.2 & $\begin{array}{l}\text { Passing or giving away their } \\
\text { husband if he was guilty }\end{array}$ & 43.4 & $\begin{array}{l}\text { Fixing the economic problems } \\
\text { in the community }\end{array}$ & 91.1 \\
\hline $\begin{array}{l}\text { Intervening the husband's family and } \\
\text { directing them to your husband in your life }\end{array}$ & 23.9 & $\begin{array}{l}\text { Accepting the mistake and } \\
\text { apologizing if he was guilty }\end{array}$ & 35.2 & $\begin{array}{l}\text { Teaching young people to have } \\
\text { a correct and informed choice } \\
\text { during marriage }\end{array}$ & 90.5 \\
\hline $\begin{array}{l}\text { Failure to know enough about their } \\
\text { husband and having quick and complete } \\
\text { marriages without knowledge }\end{array}$ & 23.7 & $\begin{array}{l}\text { Shorting and complimenting } \\
\text { despite being not guilty }\end{array}$ & 30.0 & $\begin{array}{l}\text { Developing policies to reduce } \\
\text { youth addiction }\end{array}$ & 88.7 \\
\hline $\begin{array}{l}\text { The inability of their husband to control his } \\
\text { anger when he was angry }\end{array}$ & 23.5 & $\begin{array}{l}\text { Squirm with and ignore her } \\
\text { husband }\end{array}$ & 23.1 & $\begin{array}{l}\text { Free advice to couples in small } \\
\text { towns and villages }\end{array}$ & 87.1 \\
\hline Emotional vacuum in their life & 23.4 & $\begin{array}{l}\text { Crying in the husband's arms and } \\
\text { talk to him }\end{array}$ & 21.4 & $\begin{array}{l}\text { Holding life skills training } \\
\text { classes in health centers }\end{array}$ & 86.5 \\
\hline $\begin{array}{l}\text { Discussing and prolong out a topic from } \\
\text { their husband }\end{array}$ & 22.5 & $\begin{array}{l}\text { referring to a counselor or } \\
\text { counseling center for problem } \\
\text { solving }\end{array}$ & 6.1 & $\begin{array}{l}\text { Learning life skills for couples } \\
\text { through mass media and } \\
\text { education }\end{array}$ & 86.3 \\
\hline
\end{tabular}

Table 3. The Average Domestic Violence Against Women According to the Type of Decision Making in Life Affairs

\begin{tabular}{lccc}
\hline Decision making in life affairs & Mean & Std. Deviation & Significant Level \\
\hline By husband & 140.0278 & 58.46928 & 0.000 \\
By spouse & 99.8800 & 46.16575 & 0.000 \\
By couples & 73.3825 & 20.89209 & 0.000 \\
\hline
\end{tabular}

the most significant type of violence in the community, respectively.

Table 2 shows the factors affecting violence, the strategies of women in the event of violence, and suggested strategies to the government to reducing the violence in the community. According to the results, working and financial problems, lack of proper education and training of their husband in his father's home and the interference of the husband's family and directing them to their husband in life was one of the most important causes of domestic violence between the couples. One of the most important strategies of women in the event of violence in the order of speaking and trying to solve the problem with their husband at the right time, passing or giving away the husband if he was guilty and accepting the mistake and apologizing if he was guilty, while the least strategy adopted by couples was to refer to the counselor or counseling centers for solving their problem.

Table 3 shows the rate of domestic violence according to the most important decision-maker has been shown in life. The highest rates of domestic violence occurred at a time when the important decisions in life were taken only by the husband, and the lowest rates of domestic violence occurred at a time when the important decisions in life were taken by the couples. If you want to feel the satisfaction of your life, what grade do you have from 10 grades? A total of $76 \%$ of the society surveyed were satisfied with their life. On the other hand, only $8.6 \%$ of the population surveyed identified the number of social emergency number (123).

\section{Discussion}

This study predicts $40 \%$ of violence against women, despite the possible contributing factors to domestic violence and the factors related to couples, which these results were consistent with the studies reported by Dolatian et al. [22] and Mohammad et al. [23]. In confirmation of these results, it can be said that using educational interventions for couples and related counseling, moderated the factors related to couples to prevent at least $40 \%$ of violence against women. The types of violence, legal violence (19\%), verbal violence $(18 \%)$ and emotional violence $(15 \%)$ were the most significant type of violence in the society, which these results were consistent with the studies reported by Asadi et al. [18], Derakhshanpour et al [24] and Narimani et al. [25] were similar the type of violence in society. However, the social issues, lifestyle and cultural can be influenced by the situations of cities and provinces, the results of this study can be different from other studies in other cities. This study showed that working and financial problems, lack of proper education and training of the spouse in the father's home, interference of the husband's family and directing them to the spouse in life were the most important causes of the domestic violence between the couples, which these results were consistent with the studies reported by Klomegah et al. [26], and Boonzaier et al. [27], matched the role of problems such as job and financial issues as factors associated with the introduction of violence. In addition, the results of this study which were consistent with the study reported by Masoumi et al. [28] matched the effect of 
interference of husband's families, proper education and the training of the spouse and the direction of the spouse in life affairs.

Our results showed, one of the most important strategies of women in the event of violence was to talk and try to solve their problem with the husband at the right time, to forgive or give away the husband if he was guilty and accept the mistake and apologize if he was guilty. Thus, these results can be matched with the view that social psychologists believe that using correctly educating the strategies necessary to resolve family problems to prevent any possible violence against women. Although the need for the use of counseling and psychologists to facilitate marital communication has been emphasized, but the least strategy taken by couples was to refer to counselors or counseling centers for solving their problem, which these results were consistent with the studies reported by Shamsi et al. [29] and Sudani et al. [30]. As shown in this study, the highest rates of domestic violence occurred at a time when important decisions in life were taken only by the husband, and the lowest rate of domestic violence was occurred at a time when important decisions in life were taken by the couple. These findings also confirm the role of shared decision making, mutual understanding, and the use of shared views of husband and wife to resolve personal issues and decisions, which these results were consistent with the studies reported by Ver Steegh et al. [31] and Robinson et al. [32]. Also, as shown in these results suggest that mental support as well as decision-making on the basis of the common view of the husband and wife can play a vital role in facilitating the prevention of domestic violence against women, which we found in this study. In this study, $76 \%$ of participants reported satisfaction with their lives, which these results were consistent with the studies reported by Ham-Rowbottom et al. [33], and Gillum, Tameka L et al. [34] and in other studies, it may be different in the rate of life satisfaction. Because the increase in the rate of domestic violence in married women may be related to a decrease in life satisfaction.

In conclusion, violence against women around the world is one of the priorities of public health. Although the results of the research and information collected have increased the awareness and sensitivity of the community to this problem of women's health, but shame, fervor and fear of women and the lack of accountability of the community health system have caused the silence and isolation of women victims and neglect of its consequences on their physical and mental health. The consequences of domestic violence on women's mental health include depression, anxiety, stress, suicidal behaviors, self-harm, and also the foundation of the family, which requires attention to the dimensions of the issue of domestic violence against married women. As the results of this study showed, issues such as family education and counseling before, during and after marriage, and also awareness raising for families with the social emergency system should be considered. Based on the results of this study, the development of strategic policies, such as smoking prevention, combating unemployment, solving economic problems, and training of husband and wife for life decisions can have a preventive role in domestic violence against married women which should be considered.

\section{References}

1. Abbaspoor Z, Momtazpour M. Domestic Violence and Its Re lated Factors Based a Prevalence Study in Iran. Glob J Health Sci. 2016 ;8(12):55206. doi:10.5539/gjhs.v8n12p1.

2. Nikbakht Nasrabadi A, Hossein Abbasi N1, Mehrdad N. The prevalence of violence against Iranian women and its related factors. Glob J Health Sci. 2014;7(3):37-45. doi:10.5539/ gjhs.v7n3p37.

3. Eslamlo HR, Boshehri B. [Partner violence and some related factors in attending medical legal center in Urmia city 2004 ( Persian )]. Urmia Medical Journal 2006; 18 ( 3 ): 554-61.

4. Mohammadi $\mathrm{H}$, Abedi A, et al. Evaluation of synthesized platinum nanoparticles on the MCF-7 and HepG-2 cancer cell lines, International Nano Letters. 2013;3(1):1-5.

5. Khalili M, Akbarzadeh A, et al. The effect of nanoliposomal and PE gylated nanoliposomal forms of 6-gingerol on breast cancer cells. Research Journal of Recent Sciences. 2009;2277:2502.

6. Esfahani MKM, et al. Pegylation of nanoliposomal paclitaxel enhances its efficacy in breast cancer. Tropical Journal of Pharmaceutical Research. 2014;13(8):1195-8.

7. Ahmadi L, Chiani M, et al. To evaluate the effect of formulation of Nanoarchaeosomal 6-gingerol on the growth of breast cancer MCF-7 cell line. New Cellular and Molecular Biotechnology Journal. 2015;5(19):47-52.

8. Zarei M, Norouzian D, Chiani M, Ebrahimi H, Mohammadi M, Akbarzadeh A. Advantages of paclitaxel- loaded nano niosomes to nanoliposomal formulation: an in vitro study. Int J Life Sci Bt \& Pharm Res. 2013;2:335-42.

9. Dadgar N, Alavi E, Moftakhari Esfahani M, et al. Evaluation the cytotoxicity of nanoliposomal artemisinin on breast cancer cell line. New Cellular and Molecular Biotechnology Journal. 2014;4:99-103.

10. Poy D, Akbarzadeh A, Ebrahimi Shahmabadi H, et al (2016). Reparation, Characterization and Cytotoxic Effects of Liposomal Nanoparticles Containing Cisplatin: An in Vitro Study. Chemical Biology \& Drug Design, 88, 568-573.

11. Kiss, L., Schraiber, L. B., Heise, L., Zimmerman, C. , Gouveia, N. , \& Watts, C. (2012). Gender-based violence and socioeconomic inequalities: Does living in more deprived neighbourhoods increase women's risk of intimate partner violence? Social science \& medicine, 74(8), 1172-1179.

12. http://www.who.int/International Day for the Elimination of Violence against Women/ [Accessed 25 November - 10 December 2017].

13. Adineh HA, Almasi Z, Rad ME, Zareban I, Moghaddam AA (2016) Prevalence of Domestic Violence against Women in Iran: A Systematic Review. Epidemiology (Sunnyvale) 6:276. doi:10.4172/2161-1165.1000276.

14. Sheikhan Z, Ozgoli G, Azar M, Alavimajd H. Domestic violence in Iranian infertile women. Med J Islam Repub Iran. 2014;28:152.

15. Rasoulian M, Habib S, Bolhari J, Hakim Shooshtari M, Nojomi M, Abedi S. Risk factors of domestic violence in Iran. J Environ Public Health. 2014;2014:352346. doi: 10.1155/2014/352346. [PMC free article][PubMed][Cross Ref].

16. Hamideh Hajnasiri,1Reza Ghanei Gheshlagh,2Kourosh Sayehmiri,3,*Farnoosh Moafi,1 and Mohammad Farajzadeh Domestic Violence Among Iranian Women: A Systematic 
Review and Meta-Analysis. Iran Red Crescent Med J. 2016 Jun; 18(6): e34971. Published online 2016 May 17. doi: 10.5812/ircmj.34971

17. Moghaddam Hosseini V1, Asadi ZS, Akaberi A, Hashemian M. Intimate partner violence in the eastern part of Iran: a path analysis of risk factors.Issues Ment Health Nurs. 2013 Aug;34(8):619-25. doi: 10.3109/01612840.2013.785616.

18. Zahra Sadat Asadi-Vahideh Moghaddam Hosseini-Masumeh Hashemian-Arash Akaberi.Application of BASNEF Model in Prediction of Intimate Partner Violence (IPV) Against Women. Asian Women 2013 Vol.29 No.1:27-45

19. http: //www.who.int/topics/violence/en/[Accessed 2 Mar 2016].

20. Peltzer K1, Pengpid S, McFarlane J, Banyini M.Mental health consequences of intimate partner violence in Vhembe district, South Africa.Gen Hosp Psychiatry. 2013 SepOct;35(5):545-50. doi: 10.1016/j.genhosppsych.2013.04.001. Epub 2013 May 2.

21. Devries K, Watts C, Yoshihama M, Kiss L, Schraiber LB, Deyessa N, Heise L, Durand J, Mbwambo J, Jansen H, Berhane Y, Ellsberg M, Garcia-Moreno C, WHO Multi-Country Study Team Violence against women is strongly associated with suicide attempts: Evidence from the WHO multi-country study on women's health and domestic violence against women. Social Science and Medicine. 2011;73:79-86.

22. Dolatian M, Hesami K, Shams J, Alavi Majd H. Evaluation of the relationship between domestic violence in pregnancy and postnatal depression. Scientific Journal of Kurdistan University of Medical Sciences. 2008;13(2):57-68.

23. MOHAMMAD KP, REZAEE DE, Azadmehr H, Mohammadi M. Family violence pattern prevalence, enacting or experiencing violence in men or women. 2006.

24. Derakhshanpour F, Mahboobi H, Keshavarzi S. Prevalence of domestic violence against women. Journal of Gorgan University of Medical Sciences. 2014;16(1).

25. Narimani M, AGHA MH. A study of the extent of men's violence against women and its related variables among families inhabited in Ardabil city. 2006.

26. Klomegah RY. Intimate partner violence (IPV) in Zambia: An examination of risk factors and gender perceptions. Journal of Comparative Family Studies. 2008:557-69.

27. Boonzaier FA, van Schalkwyk S. Narrative possibilities: Poor women of color and the complexities of intimate partner violence. Violence against women. 2011;17(2):267-86.

28. Masoumi SH, Ravandi Z. Factors Affecting Spouse Abuse in Women Referring to Shiraz Medical Center in 2015. Scientific Journal of Science2015;14(1):39-48.

29. Mohseni SH, Akrami B. Frequency of domestic violence on pregnant women in Arak2012.

30. Mansoori S, Nasiri D, Gholamrezayi R. Comparison of the effect of couple therapy on conflict resolution of women victims of violence.

31. Ver Steegh N. Yes, no, and maybe: Informed decision making about divorce mediation in the presence of domestic violence. Wm \& Mary J Women \& L. 2002;9:145.

32. Robinson AL, Chandek MS. The domestic violence arrest decision: Examining demographic, attitudinal, and situational variables. Crime \& Delinquency. 2000;46(1):1837.

33. Ham-Rowbottom KA, Gordon EE, Jarvis KL, Novaco RW. Life constraints and psychological well-being of domestic violence shelter graduates. Journal of family violence. 2005;20(2):109-21.

34. Gillum TL, Sullivan CM, Bybee DI. The importance of spirituality in the lives of domestic violence survivors.
Violence Against Women. 2006;12(3):240-50.

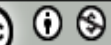

This work is licensed under a Creative Commons AttributionNon Commercial 4.0 International License. 